\title{
Ibm Untuk Peningkatan Kualitas Layanan Posyandu Melalui Perbaikan Alat Timbang Balita
}

\author{
Hana Catur Wahyuni ${ }^{1}$, Sri Mukhodim Faridah Hanum ${ }^{2}$. \\ hanacatur@umsida.ac.id \\ ${ }^{1}$ Teknik Industri, ${ }^{2}$ Kebidanan \\ Universitas Muhammadiyah Sidoarjo
}

\begin{abstract}
Abstrak: Desa Gelam terletak di Kecamatan Candi, Kabupaten Sidoarjo. Posyandu RW 5 merupakan salah satu posyandu diwilayah didesa Gelam. Posyandu RW 5 mempunyai jumlah balita yang lebih besar dari pada Posyandu lain di desa Gelam. Permasalahan yang dihadapi adalah rendahnya kedatangan balita ke posyandu karena adanya trauma yang di rasakan oleh keluarga (ibu) balita setiap kali kunjungan ke posyandu, disebabkan adanya rasa tidak nyaman selama proses penimbangan, karena faktor peralatan timbang yang "menyiksa" balita. Pelaksanaan IbM dilakukan dengan membuat alat timbang yang nyaman dan aman bagi balita. Hasil IbM menunjukkan bahwa perubahan alat timbang balita memberikan dampak positif bagi perkembangan posyandu, yang terlihat dari meningkatnya jumlah kunjungan balita, suasana yang nyaman, tidak ada tangisan balita dan hasil evaluasi terhadap $30 \mathrm{ibu}$ balita menunjukkan bahwa $100 \%$ ibu tersebut puas dan suka dengan alat yang ada.
\end{abstract}

Kata kunci: Posyandu, Balita, Alat Timbang, Nyaman, Aman.

\section{ANALISIS SITUASI}

Desa Gelam merupakan salah satu desa di Kecamatan Candi, Kabupaten Sidoarjo. Di desa Gelam terdapat 5 RW dengan 29 RT. Masing- masing RW mempunyai pos pelayanan terpadu (Posyandu) balita yang saat ini menjadi perhatian utama bidang kesehatan desa ataupun perhatian bagi pihak Pemerintah melalui Departemen Kesehatan. Posyandu merupakan salah satu bentuk Upaya Kesehatan Bersumberdaya Masyarakat (UKBM) yang dilaksanakan oleh, dari, dan bersama masyarakat, untuk memberdayakan dan memberikan kemudahan kepada masyarakat guna memperoleh pelayanan kesehatan bagi ibu, bayi, dan anak balita (Kemenkes, 2012). Posyandu desa Gelam, secara langsung dibina oleh bidang desa yang berada dalam naungan Puskesmas Candi.

Mitra IbM adalah Posyandu RW 5 (disebut Posyandu 5). Posyandu tersebut dipilih diantara 6 Posyandu lainnya, karena mempunyai permasalahan paling berat dibandingkan yang lainnya. Posyandu 5 berada pada wilayah yang berdampingan, terpisah dari Posyandu 1 , 2, 3 dan 4 yang berada disebelah barat jalan raya Sidoarjo- Malang, sedangkan Posyandu 5 berada di Timur jalan Sidoarjo-Malang. Dari sisi luas wilayah, RW 5 lebih kecil jika 
dibandingkan dengan wilayah RW 1, 2, 3 dan 4 yang berada di barat jalan. Tetapi, dari sisi data jumlah balita, Posyandu 5 mempunyai jumlah balita yang lebih besar dari pada Posyandu 1, 2, 3 dan 4. Hal ini disebabkan RW 5 merupakan lokasi baru dengan jumlah penduduk produktif (pasangan muda) lebih banyak dari RW 1, 2, 3 dan 4.

Posyandu di RW 5 dilaksanakan pada hari Kamis, minggu pertama setiap bulan dengan bertempat di balai RW 5. Jumlah balita yang tercatat pada data desa menunjukkan RW 5 terdapat 125 balita usia 0- 5 tahun. Posyandu dikelola oleh kader, yang terdiri 8 kader per posyandu. Saat ini, beberapa permasalahan (kasus) terkait mutu layanan sedang dihadapi oleh posyandu di RW 5, terlihat dari rendahnya tingkat kedatangan balita ke posyandu, antara 20 balita per bulan (25\% dari jumlah balita). Sementara, target kedatangan balita yang ditetapkan oleh Puskesmas Candi untuk desa Gelam adalah 85\% balita per posyandu. Hasil observasi dilapangan menunjukkan bahwa rendahnya kedatangan balita ke posyandu dipicu adanya trauma yang di rasakan oleh keluarga (ibu) balita setiap kali kunjungan ke posyandu, disebabkan adanya rasa tidak nyaman selama proses penimbangan, karena faktor peralatan timbang yang "menyiksa" balita. Gambaran kondisi proses penimbangan balita di RW 5 desa Gelam adalah sebagai berikut:

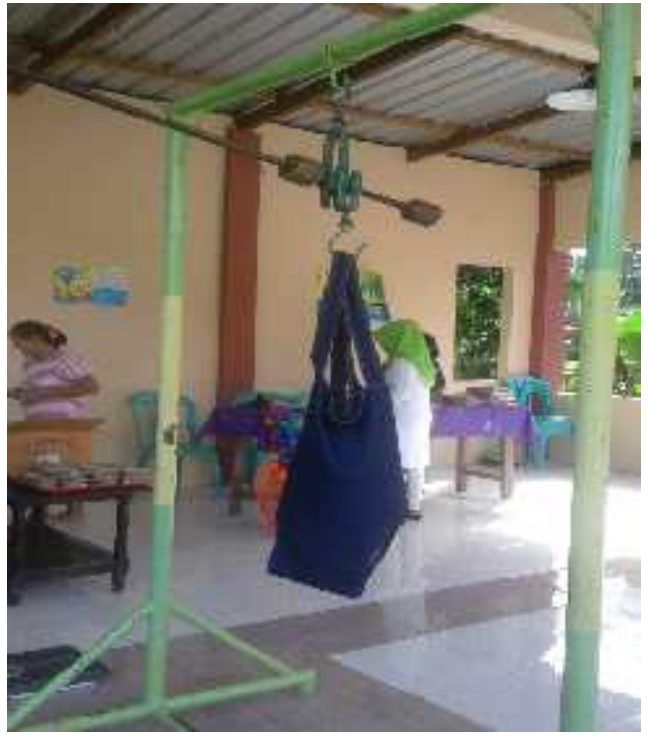

(a)

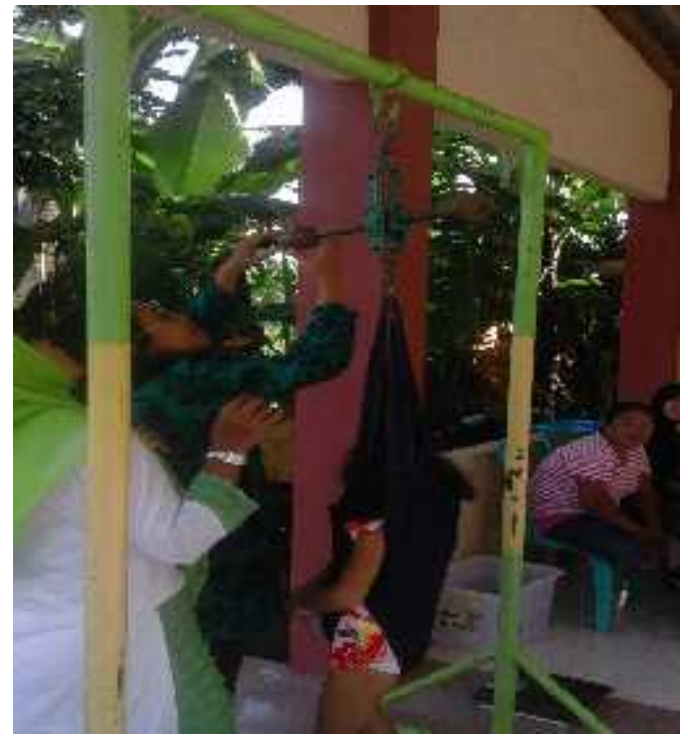

(b)

Gambar 1. (a) Alat timbang balita, (b) Proses penimbangan balita.

Gambar 1 menunjukkan proses penimbangan balita dilokasi mitra IbM. Gambar (a) adalah alat timbang yang digunakan, gambar (b) adalah posisi balita saat penimbangan. Kondisi pada gambar (b) merupakan posisi yang membuat balita tidak nyaman, sehingga pada bulan berikutnya balita tidak bersedia datang ke posyandu. Hal ini disebabkan karena alat 
Hana Catur Wahyuni ${ }^{1}$, Sri Mukhodim Faridah Hanum ${ }^{2}$

timbang yang digunakan tidak ergonomis, yaitu sebagai studi tentang aspek-aspek manusia dalam lingkungan kerjanya, yang ditinjau secara anatomi, fisiologi, psikologi, engineering, manajemen dan desain/ perancangan (Soenandi: 2013).

Oleh karena itu, IbM pada masyarakat ini bertujuan untuk menyediakan alat timbang balita yang membuat balita nyaman selama proses penimbangan, sehingga akan mendorong balita untuk selalu datang ke posyandu (alat timbang bayi ergonomis).

\section{METODE PELAKSANAAN}

Tata cara kerja dilakukan dengan merancang alat penimbangan bayi yang ergonomis sehingga proses penimbangan menjadi suatu proses yang nyaman dan aman bagi balita (Susi Erna Wati et al., 2018). Perancangan peralatan dilaksanakan dengan mempertimbangkan kemudahan memperoleh bahan dan kemudahan proses penimbangan oleh kader posyandu. Rancangan alat penimbangan dibuat dengan memanfaatkan media permainan yang selama ini sering digunakan oleh balita, yaitu kuda-kudaan. Selanjutnya, alat tersebut digantung pada alat gantungan yang sudah disediakan dengan tinggi yang disesuaikan dengan tinggi balita. Sehingga, kader posyandu tidak perlu mengangkat untuk menaikan/ menurunkan balita dari timbangan.

\section{HASIL}

Kegiatan dilaksanakan dengan meracang suatu alat timbang balita yang nyaman dan aman digunakan. Alat penimbangan bayi hasil pengabdian masyarakat yang dilaksanakan oleh penulis adalah sebagai berikut:
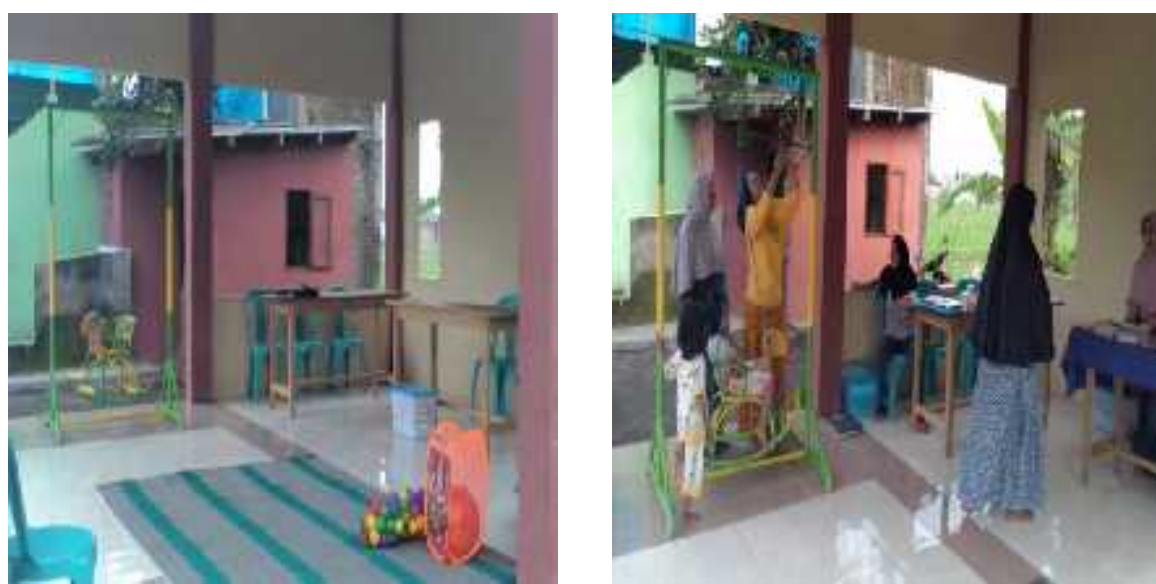

Gambar 2. Alat timbang balita hasil pengabdian masyarakat

Rancangan alat timbang balita ini disesuaikan dengan beberapa aspek, antara lain:

1. Aspek kemudahan dalam penggunaan 
Alat timbang balita yang dibuat harus mudah digunakan oleh para kader posyandu. Mudah dalam hal ini didefinisikan dalam kemudahan untuk operasional penimbangan dan kemudahan dalam penyimpanan. Mengingat, setelah pelaksanaan posyandu pada setiap awal bulan, maka peralatan harus disimpan, sehingga alat timbang didesain sebagai peralatan yang ringkas dan mudah dibongkar/ pasang. Lebih dari itu, kemudahan ini juga dihubungkan dengan kader posyandu yang secara keseluruhan berjenis kelamin perempuan, sehingga desain alat timbang disesuaikan dengan antripometri tubuh perempuan.

2. Aspek manusia (kader posyandu).

Aspek manusia dalam operasional peralatan manual sangat penting. Karena manusia merupakan motor penggerak alat tersebut (Kementerian Kesehatan RI, 2011). Oleh karena itu, alat timbang balita ini disesuaikan dengan kondisi antropometri dari kader posyandu, yang berjenis kelamin perempuan, usia lebih dari 45 tahun dan tinggi badan rata- rata $130 \mathrm{~cm}$. Alat timbang dirancang untuk mudah dipasang dan dilepaskan dari tiang penyangga dengan berat peralatan yang ringan, kurang dari $3 \mathrm{~kg}$.

3. Aspek ketersediaan bahan baku.

Peralatan didesain dengan menggunakan bahan dasar yang mudah ditemukan dilokasi sekitar. Dalam hal ini berbahan dasar rotan, yang mempunyai berat ringan. Desain bentuk dasar adalah kuda. Bentuk kuda dipilih dengan pertimbangan bahwa binatang kuda merupakan binatang yang sudah dikenal oleh para balita, sehingga tidak menimbulkan ketakutan ke balita saat akan digunakan.

Pemanfaatan alat timbang tersebut mendapat respon positif dari masyarakat. Kondisi ini terlihat dari sisi:

a. Jumlah balita yang melakukan kunjungan ke posyandu

Berdasarkan catatan kader posyandu terlihat perubahan jumlah balita yang melakukan kunjungan ke posyandu mencapai rata- rata 30 balita per bulan. Kondisi ini menunjukkan perkembangan yang signifikan dengan adanya bantuan peralatan timbang balita tersebut.

b. Perubahan suasana kenyamanan.

Hasil pengamatan dilapangan menunjukkan bahwa suasana pasca penggunaan alat timbang balita yang baru lebih menyenangkan. Suasana pelaksanaan posyandu diwarnai dengan canda dan tawa para balita, tidak ada lagi tangis kesakitan saat dilakukan penimbangan.

c. Hasil evaluasi kepuasan ibu balita 
Evaluasi tingkat kepuasan dilaksanakan dengan menggunakan kuisioner yang disebarkan kepada para ibu balita. Kuisioner disebarkan ke 30 ibu balita yang datang ke posyandu. Hasil evaluasi menunjukkan bahwa 100\% responden puas dan suka terhadap peralatan timbang balita hasil pengabdian masyarakat ini.

Perubahan-perubahan tersebut menunjukkan bahwa pengabdian pada masyarakat dengan merancang dan membuat alat timbang balita yang nyaman dan aman memberikan dampak positif ke masyarakat. Dalam jangka panjang, kondisi ini diharapkan mampu meningkatkan kualitas kesehatan balita di lokasi IbM, karena dengan peralatan timbang yang nyaman dan aman akan mampu memotivasi balita untuk datang ke posyandu. Dengan kedatangan balita setiap bulan secara periodik, maka perkembangan balita akan terpantau setiap periode.

\section{SIMPULAN}

Peralatan timbang balita merupakan salah satu media utama yang diperlukan oleh posyandu dalam melaksanakan proses operasionalnya. Kondisi alat timbang balita yang tidak nyaman mengakibatkan kurang optimalnya angka kunjungan ke posyandu. Oleh karena itu, dengan IbM ini dirancang suatu alat timbang balita yang nyaman dan aman digunakan sehingga balita tidak merasa takut atau tersiksa saat ditimbang. Alat timbang dirancang dengan memperhatikan aspek kemudahan dalam penggunaan, aspek manusia (kader posyandu) dan aspek ketersediaan bahan. Perubahan peralatan ini memberikan dampak positif bagi perkembangan posyandu yang dalam jangka panjang akan berdampak pada kesehatan balita, karena adanya pantauan terhadap kondisi kesehatan balita secara periodik.

\section{UCAPAN TERIMA KASIH}

Bersama ini kami sampaikan terima kasih kepada Universitas Muhammadiyah Sidoarjo yang telah membiayai program IbM ini melalui skim pengabdian internal tahun 2016.

\section{DAFTAR PUSTAKA}

Kemenkes. (2012). Pedoman Penceqahan dan Penanggulangan Kegemukan dan Ubesitas pada Anak Sekolah. Kementerian Kesehatan Republik Indonesia.

Kementerian Kesehatan RI. (2011). Pedoman Umum Pengelolaan Posyandu. Kementerian Kesehatan RI. https://doi.org/362.11.Ind P 
Hana Catur Wahyuni ${ }^{1}$, Sri Mukhodim Faridah Hanum ${ }^{2}$

Soenandi, I. A., Ginting, M., \& Marpaung, B. (2013). Perancangan ergonomis tempat tidur rumah sakit. Jurnal Ilmiah Teknik Industri, 1(2), 95-102.

Susi Erna Wati, Siti Aizah, Elizabeth Herawati, Rherizqi Andansari, Ifa Nilta Nafisah, \& Ika Ampril Christine. (2018). Mencuci Tangan Yang Benar Di SDN Gempolan I dan II Gurah Kediri PAK PUNG SACIPUTRI, 1(2), 90-95. Retrieved from

http://ojs.unpkediri.ac.id/index.php/PPM 